\title{
Espacios cotidianos de los rancheros californios y performatividad turística en la Sierra de San Francisco, México
}

\author{
Daniel Rodríguez-Ventura ${ }^{1}$ \\ Álvaro López López ${ }^{2}$
}

\begin{abstract}
Resumen: El giro performativo del turismo en la Geografía —emanado del giro cultural en las ciencias sociales y humanidades contemporáneas - plantea que el turismo es una práctica multisensorial de prácticas repetitivas y coreografiadas, como si estuvieran establecidas en un texto teatral. Así, en las rutas turísticas que se realizan hacia las pinturas rupestres de la Sierra de San Francisco — Patrimonio Mundial de la UNESCO— se identificaron tres tipos de performances, con base en las metodologías de la observación participante, la entrevista a profundidad y el análisis cualitativo a partir de diferentes fases de trabajo de campo entre los años de 2011 y 2019. El objetivo de esta investigación fue el identificar cómo es que los performances reconocidos en las rutas turísticas a las pinturas rupestres referidas involucran a los espacios de la vida cotidiana de los rancheros californios, herederos de un patrimonio cultural que se mercantiliza a través del turismo.

Palabras-clave: performances turísticos; pinturas rupestres; Sierra de San Francisco; rancheros californios; espacios de la vida cotidiana.
\end{abstract}

\section{Everyday life spaces of rancheros californios and tourist performativity in the Sierra de San Francisco, México}

\begin{abstract}
In the context of the cultural turn, that pervades contemporary social sciences and humanities, the Geography of Tourism has undergone a 'performance turn'. Followers of this approach see tourism as a multisensory experience in which participants perform repetitive choreographed practices as though they belonged in a theatrical script. In the tours to the World-Heritage cave paintings of the Sierra de San Francisco (Baja California Sur, Mexico) three such 'scripts' were identified. Between 2011 and 2019, fieldwork was conducted at various stages with an aim to identify the way in which tourist performances interact with the everyday life spaces of rancheros californios, whose cultural heritage the tourism industry has made available for consumption.
\end{abstract}

Keywords: tourist performances; cave paintings; Sierra de San Francisco; Baja California ranchers; everyday life spaces.

\section{Espaços da vida cotidiana de rancheros californios e performatividade turística na Sierra de San Francisco, México}

Resumo: No contexto do interesse na cultura que permeia nas ciências sociais e humanas contemporâneas, à Geografia do Turismo adoptou uma 'orientação performativa'. Os seguidores dessa abordagem veem no roteiro turístico um roteiro teatral, uma experiência multissensorial na qual os participantes realizam práticas indicadas numa espécie de coreografia. Nas visitas às pinturas rupestres do Patrimônio Mundial da Serra de São Francisco (Baja Califórnia Sul, México), três 'scripts' foram identificados. O trabalho de campo foi realizado em várias etapas entre 2011 e 2019, com o objetivo de identificar como os 'performances' turísticos envolvem os espaços da vida cotidiana dos rancheros californios, cuja herança cultural virou objeto de consumo para à indústria turística. Palavras-chave: performances turísticas; pinturas rupestres; Serra de São Francisco; fazendeiros da Baja Califórnia; espaços da vida cotidiana.

\section{DOI: https://doi.org/10.26512/patryter.v4i8.32115}

Como citar este artigo: Rodríguez-Ventura, D., \& López-López, A. (2021). Espacios cotidianos de los rancheros californios y performatividad turística en la Sierra de San Francisco, México. PatryTer-Revista Latinoamericana e Caribenha de Geografia e Humanidades, 4(8), 1-18. DOI: https://doi.org/10.26512/patryter.v4i8.32115

Recebido: 18 de junho de 2020. Aceite: 14 de outubro de 2021. Publicado: 1 de setembro de 2021.

\footnotetext{
${ }^{1}$ Candidato a doctor. Posgrado en Geografía, Universidad Nacional Antónoma de México, UNAM. ORCID: https://orcid.org/0000-0002-1488-2740.E-mail: danielrv.geo@hotmail.com.

2 Investigador Titular, Departamento de Geografía Económica, Instituto de Geografía de la UNAM. ORCID: https://orcid.org/0000-0003-0719-1316. E-mail: lopuslopez@yahoo.com.mx.
} 
Daniel Rodríguez-Ventura

Álvaro López López

\section{Introducción ${ }^{\mathrm{i}}$}

El turismo vincula individuos de sociedades radicalmente diferentes en medio de una cosificación del entorno visitado; esto ha sido particularmente evidente en los sitios de la lista de Patrimonio Mundial de la Unesco (Alvarado \& López, 2018; García \& La Calle, 2012; Sancho, 1998). Con base en el giro cultural (cultural turn), la Geografía también reflexiona sobre la mercantilización de la cultura en contextos turísticos, al abordar las transformaciones de los espacios cotidianos y las interacciones de los actores involucrados en los espacios turísticos de destino, a partir del giro performativo (performance turn); estos aspectos son la base teórica del presente artículo (Alvarado \& López, 2018; Alvarado, Zamora \& López, 2018; Larsen, 2012; Hiernaux, 2008; Edensor, 2000, 2001).

Dentro de los elementos cognitivos del giro performativo, en este artículo se consideran los aportes de la geografía del turismo (Larsen, 2012; Edensor, 2000, 2001); así, el objetivo de esta investigación es analizar el papel de los espacios cotidianos de los rancheros californios en los performances turísticos, como elementos incluidos por los guías, habitantes y/o turistas en el escenario turístico de las rutas de las pinturas rupestres dentro de la Zona Arqueológica de la Sierra de San Francisco. La organización espacial del turismo en la Zona Arqueológica de la Sierra de San Francisco se funda en la idea de proteger, conservar y apreciar arte rupestre en entornos relativamente delimitados, pero en los hechos se invaden los espacios de la vida cotidiana de los rancheros locales.

La Sierra de San Francisco es parte de la Reserva de la Biosfera El Vizcaíno, Estado de Baja California Sur, México (fig. 1), en cuyos abrigos rocosos se encuentran las celebérrimas pinturas rupestres Gran Mural y que son Patrimonio de la Humanidad de la UNESCO. El paisaje es desértico y sus actuales habitantes, los rancheros californios, son herederos de la cultura vaquera de la época misional californiana del siglo XVII, expandida posteriormente a los Estados Unidos en la cultura cowboy (Romero \& Varela, 2011; Crosby, 2010; Magaña, 2010). El Instituto Nacional de Antropología e Historia [INAH] (1994) estableció en su "Plan de Manejo para la Zona Arqueológica de la Sierra de San Francisco" [Plan de Manejo] el polígono de la "Zona Arqueológica de la Sierra de San Francisco", donde están los murales rupestres (fig. 1). En la gestión del turismo los rancheros californios fungen como guías.

Aunque para las turoperadoras las "estrellas" de la visita a la Sierra de San Francisco
Espacios cotidianos de los rancheros californios y performatividad turística en la Sierra de San Francisco, México

son las pinturas rupestres, tácita o deliberadamente incluyen en su oferta los paisajes naturales o las aproximaciones a la vida cotidiana de los rancheros californios, famosos por sus habilidades vaqueras y actividades campiranas; estos aspectos se cosifican a través del turismo, sin que los locales sean conscientes de lo que ocurre ni reciban alguna retribución extra, salvo su pago como guías de turistas.

La mercantilización de la vida cotidiana de los rancheros californios a favor del negocio turístico es un tema inexplorado en la academia, por lo que la Geografía puede reflexionar sobre las tensiones espaciales subjetivas que la introducción del turismo genera en los entornos más privados de los locales, es decir, en sus espacios de vida, cargados de sentimientos, emociones, símbolos y prácticas cotidianas tradicionales que, sin embargo, son cosificadas para y por el turismo, sin un consenso real de sus habitantes.

Ontológica y epistemológicamente esta investigación parte de la geografía humanística, centrada en la espacialidad de las vivencias y sentimientos de los sujetos (Silveira, 2006; Pillet, 2004; Buttimer, 2001; Nogué, 1985; Estébanez, 1982; Entrikin, 1976). Este paradigma geográfico, con base en la fenomenología existencial, comprende la existencia de los sujetos, sus ideas, sentimientos, experiencias, vivencias y emociones, que singularizan su relación con el mundo (Føllesdal, 1992; Estébanez, 1982; Entrikin, 1976). Esta geografía también incluye la experiencia personal de los mismos investigadores en la cocreación del conocimiento en la relación que establecen con los sujetos de estudio (Harper, 1987; Entrikin, 1976).

La presente investigación se dio en 4 fases, en los años 2011, 2013, 2017 y 2019: La primera fue de reconocimiento y observación de la vida cotidiana de los rancheros californios y sus vínculos como guías de los turistas en la Zona Arqueológica de la Sierra de San Francisco. En la segunda se observó el proceso de mercantilización de la cultura local a través de la propuesta teórica del giro performativo del turismo (performance turn in tourism) (Larsen, 2012; Edensor, 2000, 2001), en su relación con la cosificación de los espacios cotidianos de los rancheros californios y de su patrimonio territorial (Doctor, 2011; Feria, 2010; Lindón, 1997, 2006a, 2006b; Ortega, 1998; Troitiño, 1998). En la tercera se revisó la propuesta de Edensor (2000) y se incorporó un nuevo tipo de performance que este académico no había considerado. Se corroboró y validó la vigencia de los resultados obtenidos en la última etapa. 
Figura 1 - Ranchos de la Sierra de San Francisco vinculados en el turismo, 2015

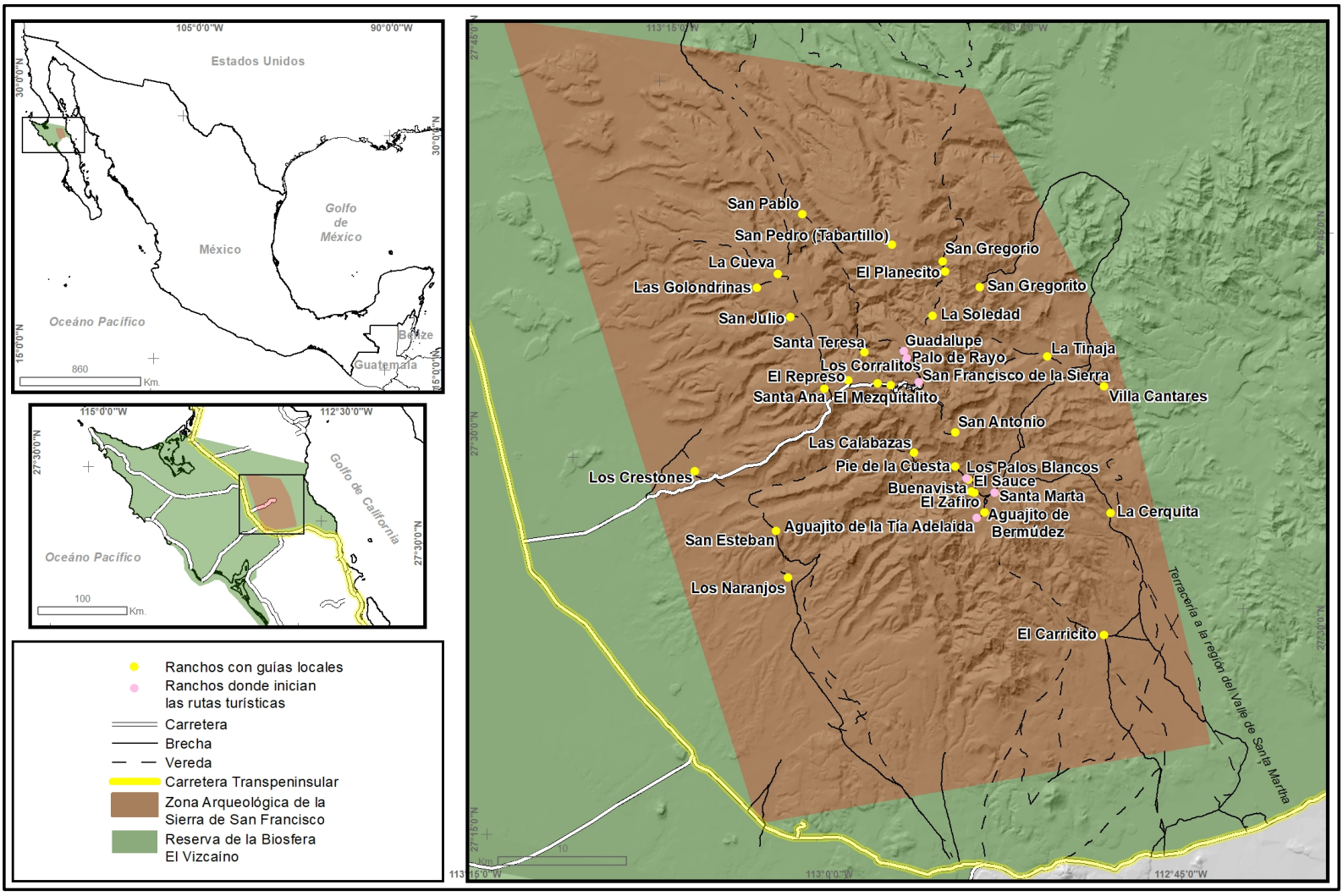

Fuente: elaboración propia con base en el Instituto Nacional de Estadística y Geografía [INEG] (2012) y en la información proporcionada por los rancheros californios durante el trabajo de campo del 2015 y 2017.

En la sección siguiente de este artículo se abordan los aspectos teóricos del giro performativo del turismo y de la vida cotidiana; posteriormente se expone el diseño metodológico de la investigación, centrado en la observación participante y las entrevistas a profundidad; luego, desde el planteamiento performativo del turismo, se describe el escenario, los directores y actores involucrados en las rutas turísticas que se realizan en la Sierra de San Francisco como parte de los espacios cotidianos de los rancheros californios; en el siguiente apartado se analizan los tres tipos de performances que se identificaron en las rutas turísticas a las pinturas rupestres de la Sierra de San Francisco y su interacción con la vida cotidiana de los rancheros locales; por último, se ofrecen algunas ideas concluyentes.

\section{El giro performativo del turismo y la vida cotidiana}

Desde el arte, el performance (performance art) es una obra en vivo que puede estar ensayada o improvisada y que, aunque toma las técnicas del teatro, pasa del texto (script) y del escenario (stage) formales a la interpretación de la acción fuera del mismo; esta estética tiene el fin de provocar reacciones entre los sujetos involucrados y de revelar situaciones desconocidas o interpretaciones diferentes sobre la vida cotidiana; el performance como fenómeno cultural posmoderno es la representación escénica del espacio como un micro mundo con su propia realidad (Schechner \& Brady, 2013; Taylor, 2011; Schechner, 2003).

Richard Schechner —influido por Victor Tuner y Erving Goffman- es considerado como el padre de los performance studies, por su enfoque analítico-estético de las ciencias sociales y por traspasar las fronteras disciplinares entre la antropología, el teatro, la lingüística, la sociología y las artes visuales, para comprender la complejidad de la construcción social de nuestros roles en la vida cotidiana y en el escenario (Taylor, 2011; Prieto, 2009). Bajo tal perspectiva, Johnson y Jaffe (2010) han abordado la performatividad escénica y cotidiana de la cultura japonesa contemporánea como una representación de sus elementos identitarios.

En sintonía, Kim (2010) sugiere que los performances no siempre son voluntarios, cuando parte del elenco es forzado a representar una realidad 
Daniel Rodríguez-Ventura

Álvaro López López

dictada por un poder fáctico, como la "utopía ilusoria" proyectada por el gobierno norcoreano en la propaganda o eventos gubernamentales, así como en la regulación de la vida cotidiana de los habitantes de tal país. También, en el entendido de que la arqueología crea imágenes del pasado a partir de la interpretación de un instante transcurrido, Russell (2006) señala que el quehacer de los arqueólogos también es performativo en el sentido de que hacen representaciones imparciales de narrativas nacionales o institucionales apegadas al mercado global del patrimonio arqueológico y del turismo.

Tanto el giro performativo como el crítico de corte marxista están vinculados con los estudios del turismo a través del giro cultural (Hannam \& Knox, 2010; Bianchi, 2009). Aunque el giro crítico se distancia de lo posmoderno al aludir a su carencia analítica para revelar la explotación de los circuitos productivos del turismo, reconoce un interés en estudios performativos que revelan la mercantilización del turismo a través de sus representaciones (Bianchi, 2009), dentro de la "teoría del performance" (performance theory). Hannam y Knox (2010) mantienen un dialogo entre los giros perfomativo y crítico del turismo para evidenciar la cosificación de la cultura, la vida cotidiana, la otredad y el medio ambiente.

Otros trabajos sólo se centran en giro performativo para evidenciar los conflictos que genera la implementación del turismo en los anfitriones, por ejemplo, algunos festivales europeos son vistos como acciones performativas que tienden a construir un discurso oficial de las identidades y patrimonio cultural, a fin de incentivar el consumo turístico, lo cual ha derivado en tensiones y ajustes en las prácticas cotidianas de los sujetos (Kockel et al., 2020).

En torno a estos aspectos se ha generado un debate académico englobado en la "teoría del performance" e insertado a la geografía del turismo, a través del "giro performativo del turismo" (performance turn in tourism), bajo el argumento de que el turismo no solo es una vivencia visual, sino una experiencia multisensorial compleja que involucra a todos los sentidos, pero no sólo eso, sino que tal experiencia está mediada por los sujetos y los elementos tecnológicos que intervienen en la práctica turística y en el consumo del espacio (Larsen, 2012; Edensor, 2000 , 2001). Nuestro trabajo contribuye a las reflexiones vertidas desde la Geografía al giro performativo del turismo, pero desde el enfoque particular de pensamiento y concepción del espacio de una de sus corrientes: la geografía humanística y sus conceptos de espacio de vida y espacio vivido.

Con base en la metáfora dramatúrgica de Erving Goffman (1959) — que apuntala la idea de que todo encuentro entre sujetos se desarrolla
Espacios cotidianos de los rancheros californios y performatividad turística en la Sierra de San Francisco, México

como una obra de teatro-, el giro performativo del turismo abstrae los componentes de la experiencia turística y los analiza desde una especie de escenario teatral, a fin de reflexionar sobre hábitos, prácticas, tematización y escenificación del espacio en el turismo (Larsen, 2012; Edensor, 2000, 2001). El planteamiento del turismo como un performance se basa en la idea de que el hecho turístico se construye con los actos repetidos de múltiples individuos implicados en un espacio determinado, y esto tiene un fuerte símil con un texto teatral, un escenario, los directores de escena y los actores (Larsen, 2012; Edensor, 2000, 2001).

El texto teatral se corresponde con la narrativa que se busca representar en un destino turístico; es una especie de libreto co-construido entre los involucrados en el turismo, a través de los imaginarios creados sobre un espacio determinado (Alvarado, Zamora \& López, 2018; Edensor, 2000). El escenario turístico toma un segmento del territorio -en un tiempo específico- para crear la realidad de un performance turístico y se concibe como un entorno organizado, tematizado y producido estéticamente, acorde con el texto teatral, sujeto a una regulación social y espacial por parte de los directores y otros agentes involucrados en el turismo (Edensor, 2000). Los directores de escena, dentro del giro performativo del turismo, controlan desde los bastidores (backstage) que mostrar o no a los turistas; se trata de situaciones coreografiadas a través de comportamientos o reglas tácitas o escritas (Alvarado, Zamora \& López, 2018; Alvarado \& López, 2018; Edensor, 2000, 2001). Dentro de todos los posibles directores de escena, en el presente artículo sólo se atiende el caso de los pobladores locales formales, es decir, los gestores-guías turísticos, intermediarios entre los turistas y los atractivos turísticos (Min, 2011).

Los actores del performance turístico son fundamentalmente los turistas, pero también pueden ser pobladores del lugar visitado — que se involucran $\mathrm{o}$ son involucrados consciente $\mathrm{O}$ inconscientemente- y cuya actuación está ligada a sus hábitos, comportamientos, cultura, vida cotidiana, clase, género, etnicidad y sexualidad; se asume que todo encuentro entre sujetos es un performance, independientemente de si se realiza en un escenario turístico o en los espacios de la vida cotidiana (Edensor, 2001; Lindón, 1997, 2006a, 2006b). En general, los turistas son los protagonistas mismos del turismo, y los locales suelen ser pobladores que participan como actores de reparto que habitan "el mundo de vida que el turista sólo visita, [son quienes realizan] las 
Daniel Rodríguez-Ventura

Álvaro López López

actividades que pueden clasificarse como cotidianas o 'normales' en los espacios y tiempos que el turista comparte sólo en un nivel de referencia" (González, 2004, p.159).

El abordaje de las rutas turísticas guiadas de nuestro caso de estudio, como un acto performativo típico dentro del turismo, se da dentro de uno de los dos marcos espaciales que precisa Edensor (2000) a) escenarios turísticos considerados como "enclaves turísticos", regulados centralmente y con límites territoriales claros, reforzados por guías que desconectan a los turistas de la vida cotidiana del entorno local, como ocurre en los parques temáticos; b) o como "espacios turísticos heterogéneos", caracterizados por una mayor flexibilidad, de modo que los turistas pueden verse más involucrados a la vida cotidiana local (Edensor, 2000). El enclave turístico planteado por Edensor (2000) no se manifiesta exactamente en nuestro caso de estudio, debido a las regulaciones sociales y espaciales de las turoperadoras.

En este artículo, el espacio receptor es un escenario turístico heterogéneo que evidencia los apegos espaciales de sus habitantes en su cotidianeidad y pone de manifiesto, desde su historicidad y territorialidad, el diálogo con su patrimonio, constituyente de la vida cotidiana de los rancheros californios (incluida la zona arqueológica). Así, los performances turísticos de esta investigación están encuadrados en un espacio turístico heterogéneo, ya que los guías locales siempre están en contacto con los turistas que llegan a la Sierra de San Francisco, y estos visitantes acceden en mayor o menor medida al ámbito de su "vida cotidiana". Ésta es el locus donde se produce y reproduce la cultura en interacción con la naturaleza (Lalive, 2008) y se integra por: a) el "espacio de vida" como entorno de las prácticas cotidianas y relaciones sociales, sobre todo del trabajo, a través de nodos estáticos y rutas de movilidad dictados por la misma cotidianidad, y b) el "espacio vivido" que es la construcción del sentido de pertenencia e identidad con el lugar en que se vive (Lindón, 1997, 2006a, 2006b).

Así, los pobladores locales de la Sierra de San Francisco involucrados en los performances turísticos, directores de escena o actores, no deben ser considerados como autómatas de un guion turístico, sino como poseedores de una "vida cotidiana", poseedores de elementos y circunstancias que han sido patrimonializadas desde su historicidad y territorialidad, y que ahora es la base del valor de cambio del turismo - propio de su espacio de vida, pero que también tienen sentimientos, emociones y apegos - propio de su espacio vivido- (Doctor, 2011; Feria, 2010; Estrada, 2000; Lindón, 1997, 2006a, 2006b; Ortega, 1998; Troitiño, 1998).
Espacios cotidianos de los rancheros californios y performatividad turística en la Sierra de San Francisco, México

Finalmente, es importante señalar que de los tres tipos de performances reconocidos por Edensor (2000), dos ocurren en las rutas turísticas comandadas por los rancheros californios: [a] El "ritual disciplinado" funciona a través de paquetes turísticos controlados desde los enclaves, en que los guías dirigen las coreografías apegadas a tiempos y rutas estipuladas, de modo que los turistas se mantienen en una burbuja de menor contacto con la realidad, lo cual es típico de los "enclaves turísticos". [b] El "improvisado" es creado por turistas que rompen la ortodoxia lineal del turismo, en el sentido de que deciden más ampliamente el ejercicio de su espacio-temporalidad, por lo que se introducen con mayor amplitud a la realidad local, así que se representan normalmente en "espacios heterogéneos". Sin embargo, Edensor (2000) no integra un performance intermedio y flexible a los señalados, necesario para cubrir el espectro encontrado en el trabajo de campo de este artículo, de modo que se propone uno tercero: "semidisciplinado con improvisaciones".

Nuestra contribución es el resultado de contrastar la teoría y lo empírico, a fin de englobar los performances turísticos ofertados en paquetes turísticos, pero que - a diferencia del tipo "ritual disciplinado"- se interpretan en un escenario heterogéneo. Por lo tanto, en el performance "semidisciplinado con improvisaciones" se reconoce el esfuerzo de la dirección ejercida por los guías de las turoperadoras por tener un control total en el desarrollo de la actuación del turista, pero que, al mismo tiempo, enfatiza las posibilidades de improvisación, según las características del propio escenario turístico. Esto pone de manifiesto que un performance semi-disciplinado con improvisaciones obedece a sus propias dinámicas cotidianas (históricas y territoriales) y no necesariamente a un control social y espacial dictado por agentes turísticos externos.

A través de estos performances, ¿en qué medida los turistas acceden más o menos al espacio de vida y al espacio vivido de los rancheros californios? Es un asunto que se discute en los resultados de la investigación.

\section{Diseño metodológico de la investigación}

Se utilizó una metodología cualitativa con técnicas de investigación ampliamente usadas en la geografía humana (Hay, 2005; Baxter \& Eyles, 1997), como el análisis de textos desde una perspectiva hermenéutica (Ángel, 2011), en que el investigador busca exponer la interpretación de los realizadores, así como la observación participante 
Daniel Rodríguez-Ventura

Álvaro López López

(Spradley, 1980) y la entrevista a profundidad (Taylor \& Bogdan, 1992), a fin de conocer las percepciones que los rancheros californios en su realización de los performances turísticos de las pinturas rupestres de la Sierra de San Francisco, como parte de su vida cotidiana.

Con los instrumentos metodológicos se focalizó la atención a los siguientes elementos observables, identificados como componentes de los performances turísticos: 1. Los espacios de vida y los vividos, como espacios cotidianos de los rancheros californios. 2. La guía de los locales (rancheros californios) a los visitantes, a fin de identificar las representaciones de su entorno y poder detectar cómo variaban las rutas turísticas en asociación con determinados discursos, así como los elementos mostrados y ocultados de su vida cotidiana. 3. Las demandas abiertas u ocultas de los turistas hacia los rancheros californios a fin de satisfacer sus expectativas de la vista y determinar la forma e intensidad de involucramiento con su vida cotidiana. 4. Finalmente, se atendió la forma en que los rancheros californios en su calidad de guías turísticos asimilan la interacción con los turistas, sus comportamientos y demandas.

De acuerdo con la propuesta de Spradley (1980) se implementó la observación participante activa, que implica un involucramiento de los observadores con las actividades de los sujetos, sin llegar al grado de tener decisiones dentro de su grupo. Durante el trabajo de campo se tuvo un rol descubierto (Flick, 2014), y se realizó en cuatro momentos:

A. En el invierno del 2011 se hizo observación participante activa, a través de una ruta larga a las pinturas rupestres y de vivir la experiencia como turista, a modo de identificar a todos los sujetos involucrados en esta dinámica turística.

B. En diciembre de 2013, con la idea de reconocer los elementos performativos de las visitas turísticas a las pinturas rupestres se dio un involucramiento con la comunidad local y se hizo observación participante activa en tres situaciones: a) ayudantía de guía de una operadora turística, en que se convivió con un grupo de cuatro turistas estadounidenses, un guía de la operadora turística y tres guías rancheros californios, en un viaje a los conjuntos de pinturas rupestres de El Ratón, el Cañón de Santa Teresa y Santa Martha, de modo que se observó la interacción entre turistas y los dos tipos de guías existentes en la región (rancheros californios y guías de operadoras turísticas); b) ayudantía del Hostal Buenaventura, realizando limpieza, mantenimiento, atención a clientes del restaurante, orientación turística y traducción entre
Espacios cotidianos de los rancheros californios y performatividad turística en la Sierra de San Francisco, México

anfitriones y turistas, de modo que se presenció la interacción entre anfitriones y turistas, la logística de los anfitriones para realizar un viaje a la ruta de las pinturas, la gestión de los servicios de hospedaje y alimentación en el rancho San Francisco de la Sierra; c) viviendo en el rancho San Francisco de la Sierra se colaboró con las actividades cotidianas de la familia encargada del Hostal Buenaventura.

C. En febrero y marzo del 2015 se realizó observación participante activa a la población en general, y diez entrevistas a profundidad a nueve guías varones rancheros californios y una mujer ranchera california - con edades entre 18 y 65 años- en los ranchos San Francisco de la Sierra, Palo del Rayo, Guadalupe, Santa Teresa, El Planecito y San Gregorio; esta situación permitió observar la dinámica turística desde la perspectiva de los anfitriones en su espacio de vida.

D. Durante dos trabajos de campo realizados en 2017 y 2019 se visitaron 21 ranchos más (La Soledad, San Gregorito, El Represo, Santa Ana, El Mezquitalito, Los Corralitos, Los Crestones, San Julio, La Cueva, San Gregorito, La Tinaja, San Antonio, Las Calabazas, El Sauce, Los Palos Blancos, Buenavista, Aguajito de Bermúdez, Aguajito de Tía Adelaida, El Zafiro, La Cerquita y El Carricito), a fin de corroborar las dinámicas reconocidas en los performances caracterizados mediante la observación participante y ampliar el conocimiento sobre la opinión de las y los rancheros californios, en relación con su involucramiento en los espacios de su vida cotidiana en el turismo.

Los resultados de la investigación fueron analizados y organizados en función de los aspectos que integran el giro performativo del turismo, pero se presentan como centrales a los que evidencian la relación entre los espacios de vida y vividos de los anfitriones con los performances turísticos. Los datos e información bibliográfica, diario y del trabajo de campo fueron procesados y analizados con el QDAS (Qualitative Data Analysis Software) Atlas.ti.; los aspectos teóricos expuestos se conformaron como códigos analíticos, mientras que los elementos empíricos se agruparon en códigos descriptivos (Saldaña, 2013; Cope, 2005). Así, se caracterizó la complejidad del escenario turístico de la Sierra de San Francisco y a la identificación de los espacios de vida y espacios vividos de los rancheros californios vinculados a éste, en consideración con el peso que tiene el Plan de Manejo (INAH, 1994), los reglamentos para turistas y para guías, que determinan sus alcances y límites de actuación. 
Daniel Rodríguez-Ventura

Álvaro López López

\section{El escenario, directores y actores: la Sierra de San Francisco y los espacios de la vida cotidiana}

Acorde con la propuesta del patrimonio territorial (Doctor, 2011; Feria, 2010; Ortega, 1998; Troitiño, 1998), no se podría considerar la patrimonialidad de las pinturas rupestres de la Sierra de San Francisco sin reconocer su vinculación con el medio físico, la historicidad y la territorialidad de sus diversos habitantes, ya que en ella convergen patrimonios materiales particulares, uno natural y uno arqueológico, así como uno inmaterial, que no se reconoce formalmente por las instituciones: la cultura y vida cotidiana de los rancheros californios. La Sierra de San Francisco tiene un área de $3,600 \mathrm{~km}^{2}$ y se constituye de montañas y mesetas de origen volcánico disectadas en cañones profundos (fig. 2); sus climas son muy seco semicálido y seco templado, con cuerpos de agua escasos, aunque tiene algunos arroyos intermitentes y pozas (Instituto Nacional de Estadística y Geografía [INEGI], 2015); la vegetación dominante es de matorral sarcocaule, matorral sarco-crasicaule y chaparral; ahí viven, además de los humanos, serpientes de cascabel, liebres, conejos, coyotes, venados, pumas y algunos borregos cimarrón (INEGI, 2015; Gutiérrez et al:; 1996).
Espacios cotidianos de los rancheros californios y performatividad turística en la Sierra de San Francisco, México

La Sierra de San Francisco fue transitada y habitada por diversos grupos humanos: paleoindígenas del Pleistoceno; indígenas del Holoceno; indígenas cochimíes que atestiguaron el arribo de los conquistadores españoles del siglo XVII; misioneros, soldados y colonos encargados de evangelizar a los indígenas y de ocupar la Alta y Baja California desde el siglo XVII hasta la independencia de México; californios y rancheros post reclamo de tierras en la época independiente; sociedades mineras y rancheras del Porfiriato y la Revolución Mexicana (Crosby, 2010; Magaña, 2010; Cariño \& Davis, 2007)

Las pinturas rupestres "Gran Mural", los petroglifos y algunas ruinas de las edificaciones misionales conforman el rico patrimonio arqueológico de la Sierra de San Francisco. En las pinturas rupestres se representan seres del mundo animalia como humanos, ballenas, venados, borregos cimarrones, entre otras, plasmadas sobre abrigos rocosos de las laderas de los cañones y se estima que fueron realizadas $-\mathrm{y}$ a veces superpuestas - a lo largo de los últimos dos milenios (Gutiérrez et al., 1996) (fig. 3). Las primeras alusiones de estas pinturas en occidente las hicieron los misioneros jesuitas en el siglo XVII, cuando revelaron que ni los indígenas cochimíes sabían de sus autores — asunto aún desconocido- (Gutiérrez et al., 1996).

Figura 2 - Sección del Cañón de Santa Teresa con andadores para la visita y protección de las pinturas rupestres, Sierra de San Francisco

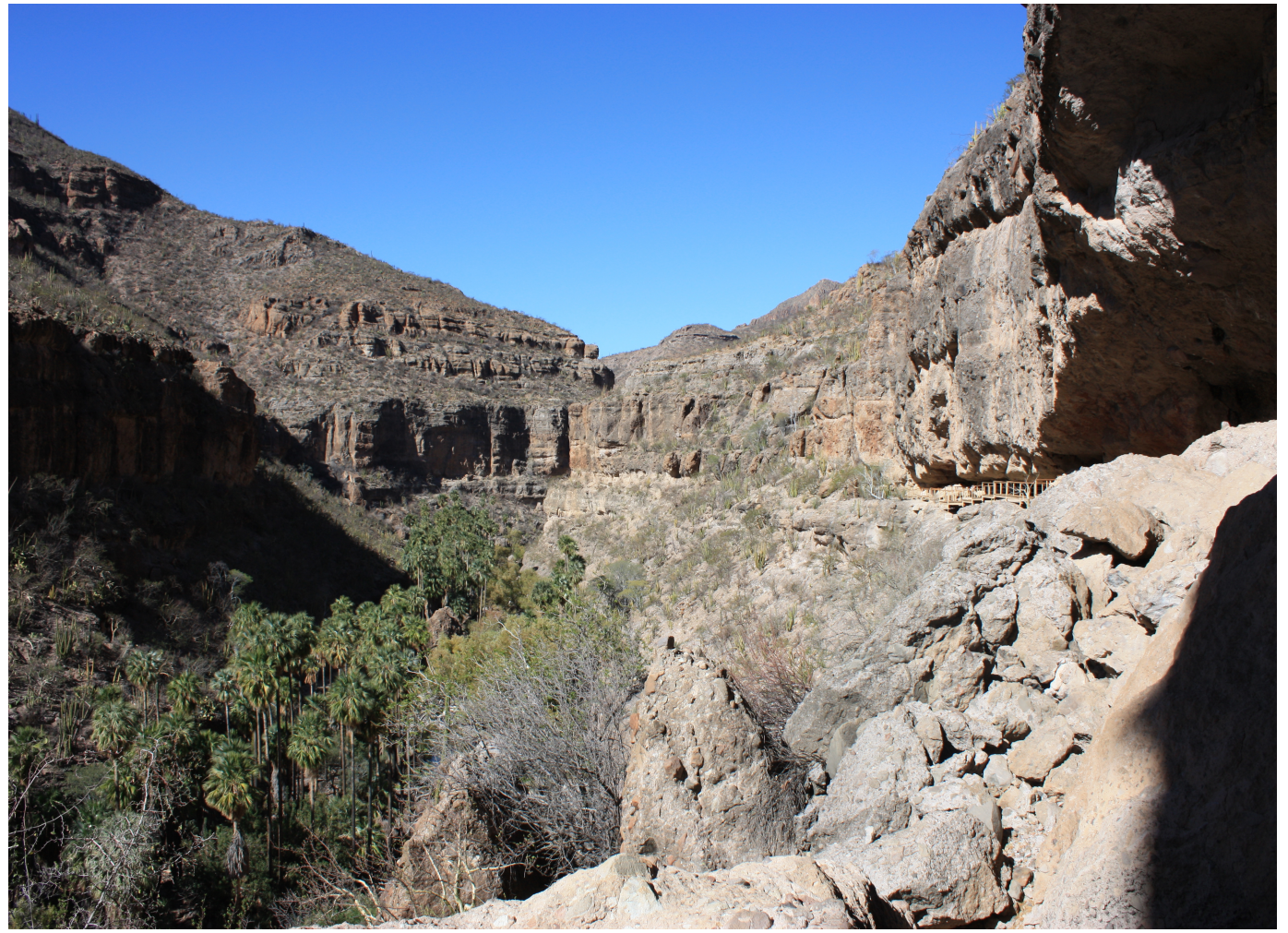

Fuente: acervo de los autores, 2011. 
Daniel Rodríguez-Ventura

Álvaro López López

La fama mundial de estas pinturas inició en 1962, cuando Erle Stanley Gardner publicó en la Life Magazine y en el libro The bidden heart of Baja algunas imágenes espectaculares (Crosby, 2010; Viñas \& Rosell, 2009; Gutiérrez et al., 1996). Por la monumentalidad de estas pinturas, en donde hay cientos de figuras humanas, artefactos de cacería y animales, en la década de 1970 Crosby y Hamblenton las caracterizaron como del estilo "Gran Mural" (Gutiérrez, 2013; Hambleton, 2010; Crosby, 1997; Gutiérrez et al., 1996) (fig. 3).

Entre los años de 1991 y 1994, el INAH (1994) delimitó el polígono de la Zona Arqueológica de la Sierra de San Francisco y elaboró el Plan de Manejo, el cual determina como estrategias para la preservación sustentable del patrimonio arqueológico, la investigación científica, la conservación de los sitios de pinturas rupestres y la administración de visitantes. En 1993 el arte rupestre de la Zona Arqueológica de la Sierra de San Francisco fue inscrita en la lista de Patrimonio Mundial de la UNESCO (Gutiérrez et al., 1996). Así, el año 1962 marcó el inicio de un fenómeno detonador del turismo en la zona, acompañado de daños y saqueos al patrimonio arqueológico, mientras que el año 1993 determinó una nueva etapa con regulación de las visitas y el turismo, gestionada por el INAH (1994).
Espacios cotidianos de los rancheros californios y performatividad turística en la Sierra de San Francisco, México

Durante el periodo misional de la Nueva España a la Alta y Baja California, la localidad de San Francisco — próxima a los cañones donde están las pinturas rupestres - había un rancho y una capilla que ayudaban al descanso en la ruta del Camino Real (Crosby, 2010); en 1762 San Francisco tenía 78 habitantes, los cuales ya se habían convertido en rancheros californios — descendientes de los soldados y trabajadores que los jesuitas llevaron a la península en el siglo XVII para la construcción de misiones y el sostenimiento de una economía basada en la explotación ganadera extensiva y la agricultura en huertos- Estos rancheros son los ascendientes de la actual población ranchera que vive en lo que hoy día se llama San Francisco de la Sierra (antes solo San Francisco) y que conviene aludir a su genealogía, pues en función de ello se ha construido su espacio de vida y patrimonio cultural.

La población ranchera actual reconoce de manera generalizada que tiene una genealogía muy larga y rastreable en un punto de origen: el "Tata Ventura", es decir, Buenaventura Arce, quien fue nieto de Sebastián Constantino Arce (Crosby, 2010). “'Tata Ventura' era el papá de Lucas, Lucas era el papá de Cesario; y Cesario era el papá de Severiano; y Severiano era el papá de Loreto; y Loreto era el papá de mi mamá" (Entrevista concedida n. 10, Rancho San Francisco de la Sierra, México, 2015).

Figura 3 - Segmento del mural de la Cueva Pintada, Cañón de Santa Teresa, Sierra de San Francisco

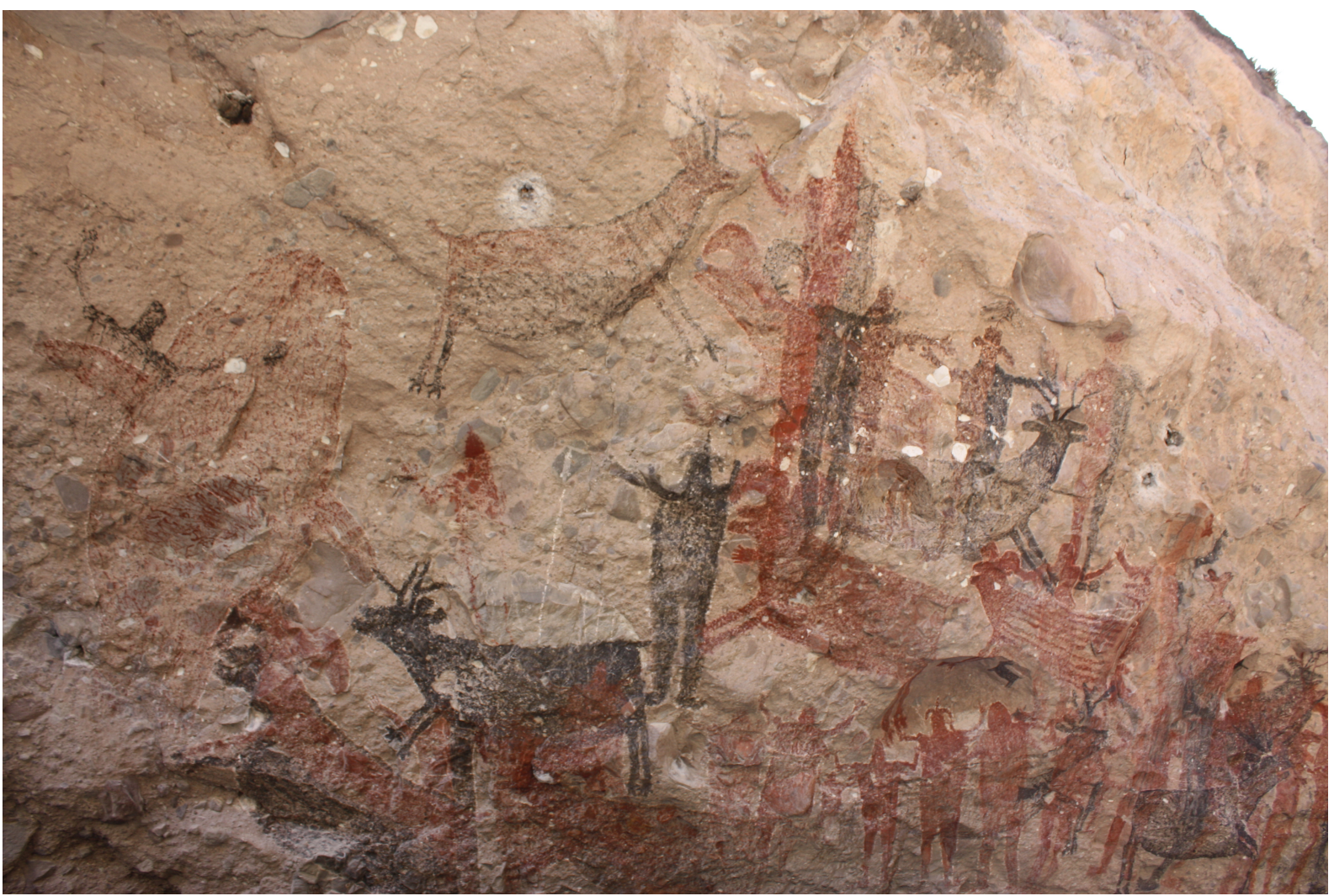

Fuente: acervo de los autores, 2011. 
Daniel Rodríguez-Ventura

Álvaro López López

"Tata'ventura", cacique de la Misión de San Ignacio, reclamó varios ranchos después de la Independencia de México, y en 1840 recibió el título de propiedad del rancho San Francisco (Crosby, 2010).

La Península de Baja California tiene como principal vía de comunicación terrestre la Carretera Transpeninsular, la cual se conecta con la Sierra de San Francisco a través dos vías que son en su mayoría terracerías, una que parte de la localidad más poblada, es decir, de San Francisco de la Sierra, y otra que sale del Valle de Santa Martha; Además de San Francisco de la Sierra, en esta área montañosa hay 80 asentamientos humanos (INEGI, 2012) de ellos, se identificó en el trabajo de campo de esta investigación que 33 son ranchos vinculados al turismo $\mathrm{y}$, en su conjunto, suman a unos 250 habitantes (46.8\% son mujeres y $53.2 \%$ hombres) (fig. 1).

Estos habitantes heredaron las prácticas de autosuficiencia de la época misional jesuita y continúan emplazadas en la unidad productiva denominada como "rancho", en donde hay casa y huertos en los que se cultivan y procesan productos mediterráneos misionales (vid, olivo, dátil y cítricos, como la naranja), se explotan a los animales de granja y carga, se curten pieles para la talabartería, se realiza la cabalgata y se construyen represas (Romero \& Varela, 2011; Crosby, 1997). La ganadería caprina extensiva, la producción de queso de cabra y otros derivados, así como el turismo, se incorporaron durante el siglo XX y, junto a la ganadería vacuna, conforman las principales fuentes de ingresos en la Sierra de San Francisco. La vestimenta del ranchero californio varón, que consiste en sombrero, camisa, pantalones, chamarra, polainas, chaparreras o armas, y teguas — calzado tradicional_-, es parte fundamental de su identidad y se ha convertido en un atractivo turístico.

Con base en la observación participante y las entrevistas a profundidad se identificó que su "vida cotidiana" y prácticas cotidianas en el territorio se construye: 1. A partir de un "espacio de vida" dado por el rancho (huerta, corral, quesera, casa de monturas, entre otros); las áreas para el campeo de vacunos, cabras y otros animales de carga; el entorno natural de los cañones, mesas y arroyos (fig. 1 y 2); las pinturas rupestres (fig. 3); y los caminos. 2. El "espacio vivido" se conforma del rancho y el espacio peri-doméstico que son la base de su reproducción económica, social y cultural, pues ahí yace la afirmación de la identidad y orgullo como "rancheros californios", con una carga de sentimientos asociados con el amor, apego y orgullo de lo que les heredaron sus padres y antepasados, pero también son espacios de privacidad y seguridad; aunque las mesas y cañones albergan a las
Espacios cotidianos de los rancheros californios y performatividad turística en la Sierra de San Francisco, México

pinturas rupestres que atraen a los turistas y que son la fuente de una creciente actividad económica, en realidad los rancheros han desarrollado poco apego a este patrimonio, con excepción de aquellos que interactúan frecuentemente con éste, a través del turismo.

Con la publicación y puesta en marcha del Plan de Manejo se reguló el turismo y se estableció que sólo se permite ser guías de turistas a los rancheros californios varones de más de 18 años, de modo que aquellos que lo desean se pueden anotar en la lista del "rol de guías", para llevar visitantes a las pinturas rupestres; la convivencia con ellos les conecta más y más a unas pinturas rupestres que antes carecían de su interés, pero que poco a poco van despertando su atención y conexión emocional:

[...] Primero uno nomás las miraba y como si nada. Pero me doy cuenta ahora que nomás las miraba y como uno está bien impuesto [...] a uno como que no le importaba [...] Pero ahora, ya después, pues ya uno se da cuenta, que con tanta gente que viene, ya uno empieza a pensar más. [...] ya ahorita me pregunto [...] ¿Cómo las hicieron? Tan altas, tan arriba [...] Primero yo no más las miraba y decia "iAh, las pinturas!" [...] Ahora todo es diferente. [...] Porque esas pinturas tienen cuántos años, y tiene un color todavía. Se ven bien claritas. Venados, borregos, tortugas, ballenas, monos [...]. (Entrevista concedida n. 7, Rancho San Gregorio, México, 2015).

Las rancheras californias no trabajan directamente en el turismo, sino tras "bastidores", en la preparación del equipo que los rancheros requieren para sus viajes como guías y cuando los turistas penetran a sus espacios de la vida cotidiana; además, ellas no tienen una vinculación cercana con las pinturas rupestres; no obstante, como acuerdo comunitario, ellas tienen el derecho de heredar el número del rol de guía de sus esposos si murieran; en esta circunstancia, y dado que la comunidad asume tácitamente que el trabajo con turistas es una actividad propia de varones, cuando un ranchero californio de la confianza de una viuda toma el turno que antes tenía su esposo, puede o no aceptar un pago simbólico de ella.

\section{Performances turísticos e interacción con la vida cotidiana de los rancheros californios}

Como se señaló en el segundo apartado de este artículo, los tres tipos de performances identificados en las rutas turísticas de la Sierra de San Francisco son "ritual disciplinado", "semidisciplinado con improvisaciones" e "improvisado". 
Daniel Rodríguez-Ventura

Álvaro López López

La performatividad turística asociada a la vida cotidiana de los rancheros californios depende, entre otros aspectos, de las motivaciones de los turistas, la duración de su viaje, si llegan a la Sierra de San Francisco motu proprio o con un guía externo; pero sin duda todo está mediado por el "Plan de Manejo" (INAH, 1994). Un involucramiento limitado de los turistas en la zona sólo les permite rasguñar el "espacio de vida" de los rancheros californios (mientras se mantienen en las rutas hacia las pinturas rupestres), y ello les reditúa poco económicamente; cuando los turistas interactúan más con los rancheros pueden acceder más fácilmente a su "espacio vivido" (entornos más íntimos, como sus ranchos), lo cual suele ser más redituable para los locales, en forma de regalos, vínculos sociales, etcétera.

El Plan de Manejo es la parte principal de un "libreto" tácito que redunda en la coreografía de las rutas turísticas a las pinturas rupestres, pues establece las áreas en que los entes involucrados pueden recorrer, las cuevas que se pueden visitar, los espacios de camping, etcétera; de este Plan se derivan los reglamentos para visitantes y guías turísticos que se regulan los comportamientos de los sujetos del turismo; tras "bastidores", los turistas interesados en ingresar a las pinturas rupestres debe tramitar un permiso en el centro regional del INAH de San Ignacio (al sur de la Sierra de San Francisco), o con los coordinadores de los ranchos San Francisco de la Sierra o Santa Martha (fig. 4); aquí también se debe contratar a un guía ranchero local, cuyo precio se
Espacios cotidianos de los rancheros californios y performatividad turística en la Sierra de San Francisco, México asocia a la dificultad de acceso a los sitios arqueológicos, al número de días de recorrido y el uso de animales de carga (para personas y equipajes). Quienes llegan en turoperadora se evitan hacer estas negociaciones, pero su margen de involucramiento en la vida cotidiana de los rancheros se reduce. Tales turoperadoras se localizan en México (San Ignacio, Guerrero Negro, Loreto, La Paz, Ensenada, Ciudad de México), Estados Unidos (San Diego) y Alemania. En la figura 5 se muestran algunas fotografías de Instagram que ilustran elementos que los turistas incluyen en sus performances estudiados.

\subsection{Performance ritual disciplinado}

Este se da cuando los turistas llegan a la Sierra de San Francisco al cobijo de una turoperadora externa; los turistas siempre deben ir acompañados por un ranchero californio durante su estancia, pero el guía foráneo mantiene el control espacial y social de los turistas de forma estricta, debido al poco tiempo que permanecen en el lugar, por lo que estos interactúan con la naturaleza y cultura local en forma reducida. En concreto, esta interacción inicia cuando los turistas llegan al Hostal Buenaventura del rancho San Francisco de la Sierra, en donde el guía local se suma al viaje, y se continúa por una ruta de fácil acceso hacia la Cueva El Ratón, que dura unas dos horas, por lo que la presencia de los rancheros californios para los turistas les resulta efímera.

Figura 4 - La Sierra de San Francisco como el escenario de los performances de las pinturas rupestres

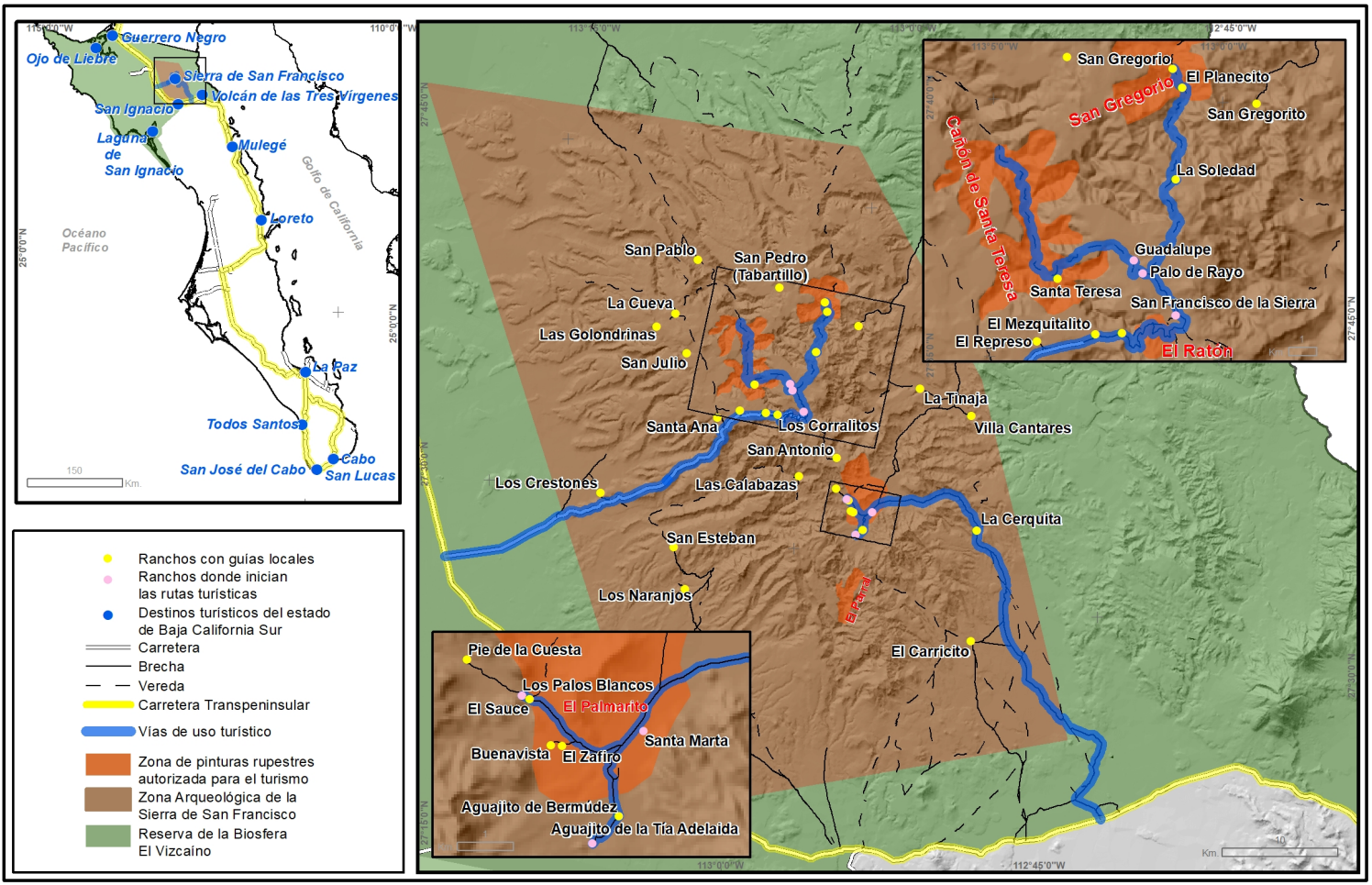

Fuente. elaboración propia, 2020. 
Figura 5 - Fotografías de la Sierra de San Francisco publicadas en Instagram por parte de los turistas, durante sus performances turísticos

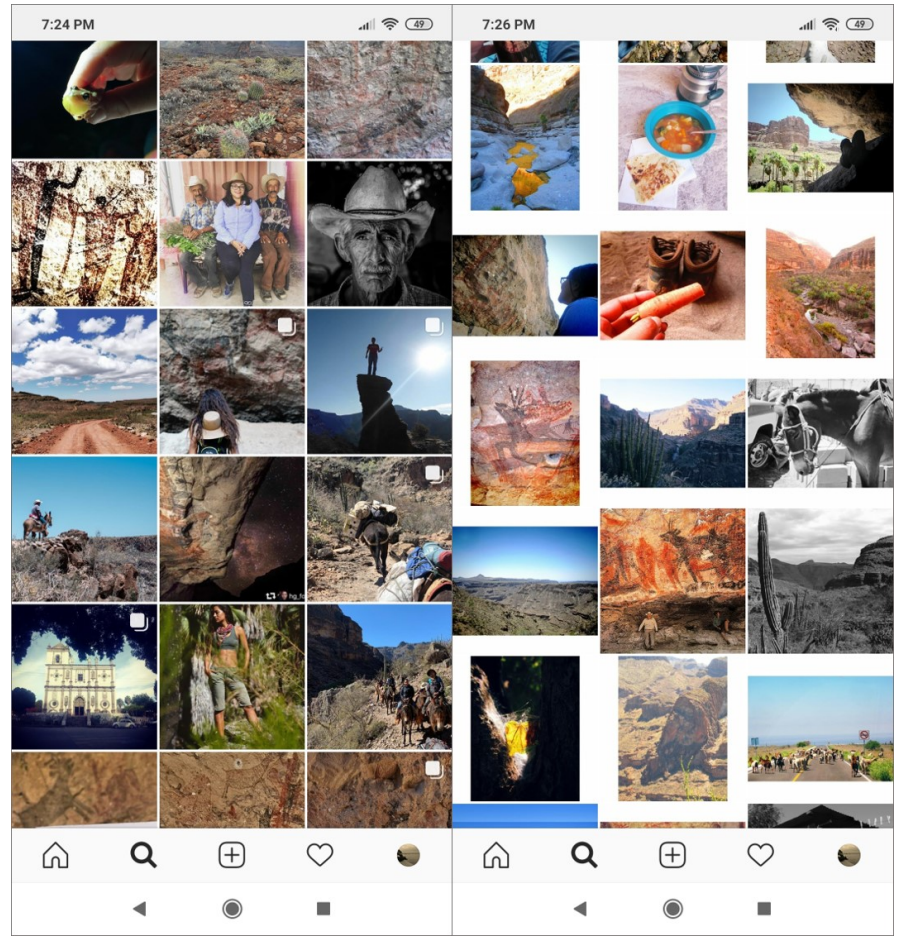

Fuente. capturas de pantallas obtenidas de Instagram, a través del hashtag \#Sierradesanfrancisco, 2020.

El guía externo detalla en idioma español o inglés la información del sitio arqueológico, del paisaje natural y cultural, hace comentarios anecdóticos de los rancheros californios. Los turistas, a través de los ojos de los guías externos, observan a los guías rancheros como objetos decorativos del entorno; después de caminar un sendero, el guía ranchero se encarga de abrir las rejas de la Cueva El Ratón y, con ello, adquieren un papel de mayor interés para los turistas quienes, mientras admiran la espectacularidad de las pinturas rupestres, suelen acercarse a ellos para preguntarles asuntos relativos a su relación con estas obras de arte; los rancheros californios, comúnmente desconectados de sus interlocutores, no logran desarrollar frases largas.

Al regresar al Hostal Buenaventura, los guías rancheros aún pueden ser escrutados por algunos turistas que les resultan distantes, pero se mantienen en el entorno bullicioso a la espera de recibir su pago y, si es posible, las propinas. Cuando se amplía el tiempo de la estancia de los turistas en la localidad, sobre todo para comer, tienen la posibilidad de conocer un poco más de la vida cotidiana de los locales; en el fervor de la comida y cuando el hambre arrecia, las pláticas se tornan menos parcas y provocan que los turistas se interesen más por los locales, sus experiencias, hacerse fotografías con ellos y con el entorno y hasta comprar artesanías.

\subsection{Performance semi-disciplinado con improvisaciones}

Lo que distingue a este performance del anterior es que los turistas tienen un libreto más desarrollado, en el sentido de que se han informado previamente sobre el arte rupestre de la Sierra de San Francisco y de sus habitantes, lo que les estimula a apreciar con más detalle el medio natural, arqueológico y cultural, a mostrar un trato cordial y a profundizar sus relaciones con los rancheros californios. Este performance siempre está dirigido por un guía de una operadora turística, pero al grupo de turistas se suma un guía ranchero local en el papel de co-director.

También en este peformance se puede visitar la Cueva El Ratón - la más cercana al rancho San Francisco de la Sierra, punto de entrada a la Sierra de San Francisco (fig. 4)—, pero sobre todo se visita el Cañón de Santa Teresa — donde están las cuevas Boca de San Julio, Los Músicos, La Pintada, La Soledad y Las Flechas-, el Cañón del Palmarito -que contiene las pinturas rupestres de $\mathrm{La}$ Serpiente, La Súper Nova, Corralitos, El Mono Parado, El Torotal y El Tabardillo- y el Cañón de San Gregorio -en el que se encuentran varios restos arqueológicos, además de las pinturas Gran Mural-. Para acceder a la ruta del Cañón de San Gregorio se requiere, además del guía local, de un custodio del INAH (1994), de manera que realizar 
Daniel Rodríguez-Ventura

Álvaro López López

esta ruta demanda de los turistas un alto grado de involucramiento con el patrimonio local.

Para hacer estas rutas se requiere de cabalgar o hacer caminatas largas por ranchos, huertas, áreas de pastoreo de cabras y vacas, y que se acampe por dos y tres noches. Los guías externos saben que los turistas revolotean imágenes estereotipadas que se han difundido ad nauseam sobre los rancheros californios, por lo que buscan aproximarlos a ellos para hacerles fotografías, incentivar a que conozcan y retraten sus ranchos y corrales, promueven el que conozcan sus vestimentas, gastronomía, etcétera (fig. 6). El guía de la turoperadora procurará cumplir con los tiempos planeados para la visita, pero en este performance los turistas no sólo tienen una mayor interacción entre los guías externo y local, sino que se esmeran en improvisar diálogos con los rancheros del Hostal Buenaventura, con individuos que durante la caminata o cabalgata se muestran proclives a responder sus preguntas o con gente de los ranchos de Santa Martha, Los Palos Blancos y El Sauce, que pudieran estar a su paso.

Los guías externos tienen un papel privilegiado como directores cuando los turistas dependen de su traducción para sostener la comunicación con los rancheros; es común que los turistas deseen saber cómo es que los rancheros
Espacios cotidianos de los rancheros californios y performatividad turística en la Sierra de San Francisco, México

valoran su patrimonio, la naturaleza que les rodea, cómo sobreviven, cómo es su trabajo y cotidianidad. Durante el performance, el guía ranchero se abre más a los turistas y procura comunicar lo que estima más interesante y valioso de su entorno, por lo que se va convirtiendo en un director de la escena más dominante, desde el momento en que preparan a los animales de carga, acomodan las sillas de montar, interactúan con otros rancheros, indican los pasos y tiempos seguros para cruzar obstáculos en las veredas, dosifican el ritmo de las caminatas, refieren los elementos de peligro y abren las rejas o indican que han llegado a un sitio de pinturas rupestres (fig. 7).

Antes de caer la noche el guía local indica el sitio para acampar; los turistas suelen preparar alimentos y bebidas, y es el momento en que todo el elenco del performance se reúne; los guías rancheros ocupan posiciones centrales al momento que los turistas hacen sus preguntas; se arrecia el deseo de penetrar a sus espacios vividos, sus casas, sus huertos, sus familias, el curtido de pieles, el trabajo de talabartería, la construcción de represas, la elaboración de quesos, la remembranza de su participación en documentales o películas, etcétera. Los guías foráneos, los guías rancheros y los turistas negocian estas visitas.

Figura 6 - Turista fotografiando la casa del Rancho Santa Martha

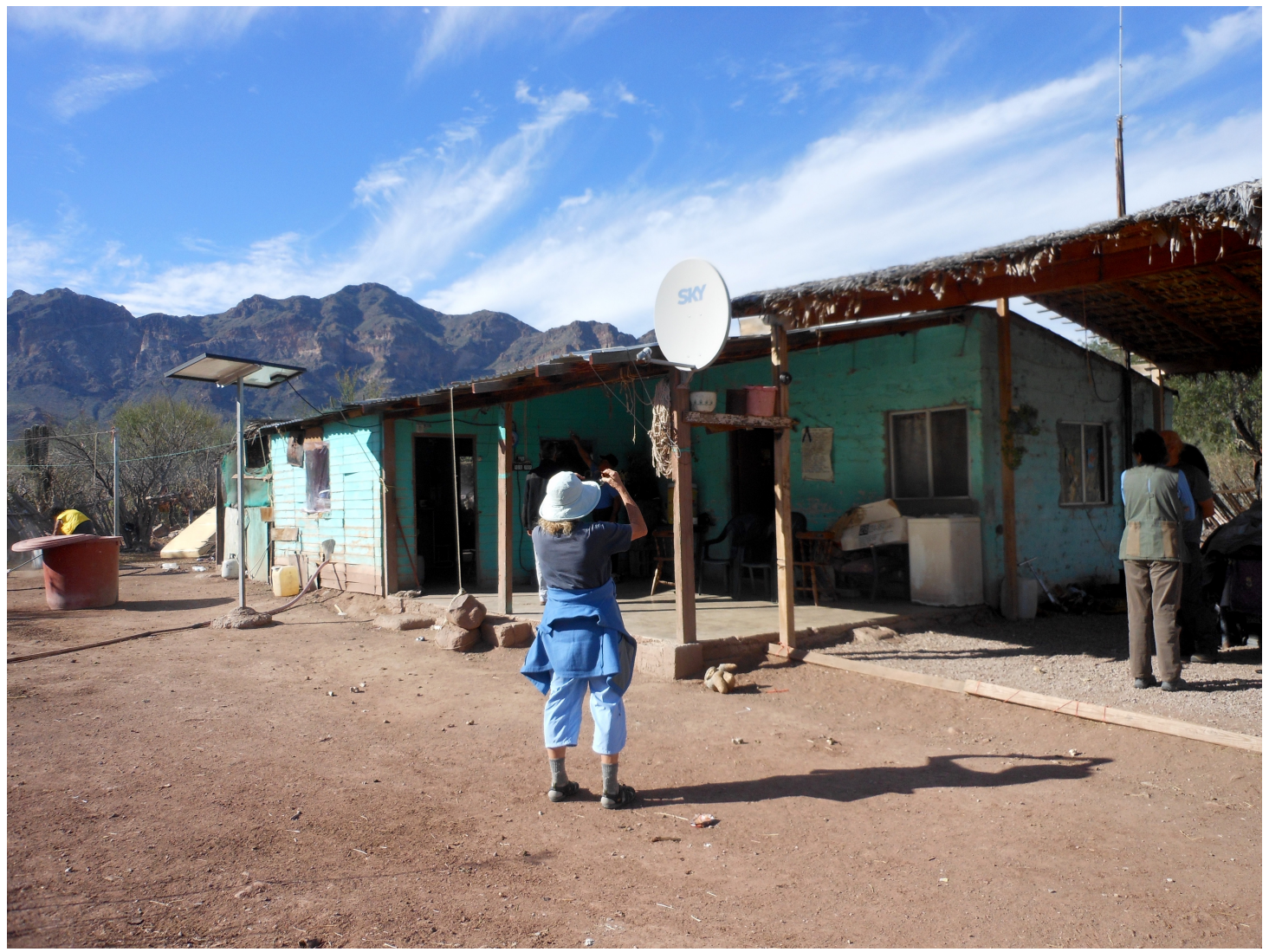

Fuente: acervo de los autores, 2013. 
Figura 7 - Turistas fotografiando a los rancheros californios durante la captura de mulas en el Cañón de Santa Teresa, previo al final de su viaje

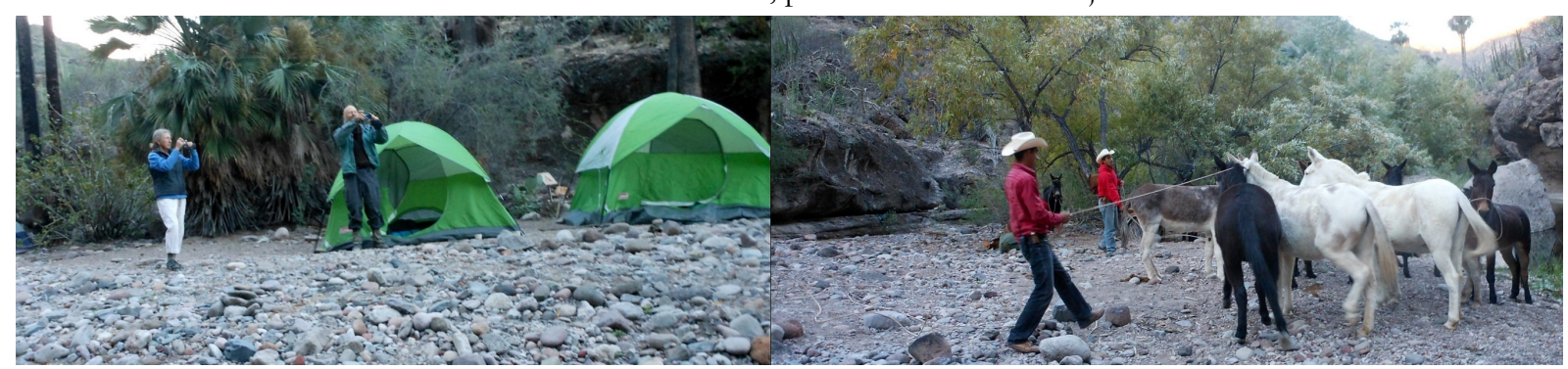

Fuente: acervo de los autores, 2013.

A la par que los guías locales fungen como directores de escena, encarnan la figura del ranchero californio, y al aumentar la convivencia con los turistas, el texto teatral va teniendo improvisaciones, se agregan elementos de representación que demandan los turistas, en un intento de descubrir algo más profundo; a veces los rancheros rememoran experiencias que han tenido con relación al arte rupestre, la naturaleza o su vida personal y es entonces que hasta pueden modificar las rutas originales y que se van ofreciendo como pequeños regalos del recorrido; los turistas se van posicionando como actores aventureros involucrados en experiencias auténticas y propias del espacio vivido local:

Pues sí, en Santa Teresa yo he visto al muchacho que está curtiendo también la piel. Yo siempre los llevo para que se den cuenta cómo viven abi, me ha tocado llevar gente por abi, llegan hasta la hornilla. Porque tienen una hornilla asi de tierrita, donde hacen la comida y a la gente le llama mucho la atención eso. La casita es de palmas y tienen todo seco, las casas son de adobe, ya viejonas. También a la gente le llama cómo hacen bajar todo a base de burro. (Entrevista concedida n. 3, Rancho Guadalupe, México, 2015).

Uno de los recorridos turísticos es manejado por una operadora estadounidense enfocada a dar a conocer el arte rupestre y la vida de los rancheros californios —de San Francisco, Palo de Rayo, Guadalupe, La Soledad, San Pedro, San Gregorio, San Gregorito, entre otros ranchos del Valle de Santa Martha- (fig. 4). El libreto de esta turoperadora se inspira en las vivencias que los exploradores como Crosby, Garner o Hamblenton tuvieron en la Sierra de San Francisco, plasmadas en el documental "Corazón Vaquero: The heart fo cowboys" (2008). Los turistas que llegan por esta vía ya conocen con amplitud y han idealizado el arte rupestre y la vida vaquera de los anfitriones, por lo que su deseo es vivir este periplo de la misma manera a los exploradores del siglo pasado.
En tanto actores, estos turistas teatralizan su desempeño con gran fidelidad, buscan mimetizarse con los rancheros californios a través de su lenguaje corporal y vestimenta tradicional, al grado que los propios guías locales, custodios y sus familiares ofrecen el acceso a su espacio vivido; turistas y rancheros californios prácticamente se mimetizan en los espacios de vida y vividos, cantando canciones rancheras, cocinando, arreando vacas y cabras; se crean lazos amistosos que suelen perdurar por muchos años, e incluso estos turistas han invitado a algunos de sus guías rancheros a sus casas en Estados Unidos y, así, corresponderles:

Ellos quieren venir aqui, porque les gusta mucho trabajar lo que uno trabaja, verlo trabajar a uno, como uno ya está bien impuesto aquí y conoce todo... Pero yo si me doy cuenta de que el turismo si llega, y llega muy contento. Le gusta mucho lo que se trabaja aqui, lo de la vaqueta y todo eso les llama mucho la atención, los cercos que están bechos en la buerta, que están bechos de piedras. Me doy cuenta de que les llama mucho la atención, que hay mucho trabajo para hacer, las casas, todos los rebajes que bicieron de muchas piedras. Aqui a San Gregorio hay personas que quieren venir al rancho, no porque están las pinturas sino a visitar a la familia, o ir al rancho. No, no habia pensado que esto fuera un recurso turístico, pero es algo bueno, la gente quiere venir, asi pues, como ir a las ballenas (Entrevista concedida n. 7, Rancho San Gregorio, México, 2015).

Lo anterior hace notar la pertinencia de analizar cierto tipo de performatividad turística desde el "performance semi-disciplinado con improvisaciones", puesto que la naturaleza homogénea de la Sierra de San Francisco es un escenario teatral en donde convergen el patrimonio material e inmaterial vivo, lo cual es difícil de regular por los directores de la turoperadoras, ya que esta conjugación suele conducir a los turistas a improvisar los guiones que "compraron" en sus paquetes turísticos y, así, incluir en su experiencia prácticas cotidianas de los rancheros californios y visitas a huertos, corrales y casas. 
Daniel Rodríguez-Ventura

Álvaro López López

\subsection{Performance improvisado}

Es característico de este performance que los turistas llegan por sus propios medios a la Sierra de San Francisco y prescindan totalmente de los servicios de las turoperadoras, de hecho, en gran medida su presencia aquí es circunstancial, por ejemplo, mochileros, automovilistas, motociclistas o ciclistas que recorren diferentes sitios turísticos de la península de Baja California, como Los Cabos, Loreto, San Ignacio, Guerrero Negro (fig. 4), al enterarse de las pinturas rupestres de la Sierra de San Francisco deciden aproximarse y visitar la Cueva El Ratón o El Palmarito. Aunque con ellos se mantiene un guía ranchero, es común que la visita no tenga una ruta muy definida; el ranchero sabe que los turistas suelen desconocer el entorno local, de modo que la comunicación puede ser tan prolija o parca como se den las condiciones momentáneas de cada una de las partes.

Puesto que las posibilidades de interacción son indefinidas, existe la posibilidad de una mayor libertad para que los turistas decidan su desplazamiento, siempre que el acceso de los espacios esté permitido por el Plan de Manejo; los intereses personales y habilidades de comunicación pueden ampliar o reducir el acceso a la vida cotidiana de los rancheros, y entonces puede ocurrir que sólo se visite una sección de las pinturas rupestres y que los turistas dejen la Sierra de San Francisco o que puedan lograr charlas largas, visitar sus casas, comprarles suvenires, tomarles fotografías a ellos y sus casas, corrales o jardines. Contrariamente a lo que se podría pensar, en el sentido de que una visita turística organizada pudiera permitir una mayor interacción entre los turistas y el espacio de vida de los rancheros californios, las posibilidades de interactuar y aproximarse al espacio vivido, de manera más intensa, se dan en función de las habilidades de comunicación que ambas partes tengan y de la empatía lograda.

Si las experiencias turísticas son gratas para turistas y guías locales (o más positivas que negativas), las posibilidades de que los turistas regresen y fortalezcan su relación con sus conocidos es mayor $y$, de esa manera, aproximarse aún más a sus espacios vividos:

Les dije, no hay problema, "arrieros somos y en el camino andamos y pues nos encontramos", y se fueron para Hermosillo, no les cobre el burro, se fueron apenados porque no me alcanzaron a pagar. Como a la semana un hermano de mi esposa two un problema con un niño cuando nació y lo llevaron a Hermosillo, entonces yo le bablé a ese muchacho y fueron hasta el aeropuerto a recibirlos y los llevaron al hospital infantil y a su casa en Hermosillo. ¿Qué tal si yo me pongo a cobrarles un montón? (Entrevista concedida n. 3, Rancho Guadalupe, México, 2015).
Espacios cotidianos de los rancheros californios y performatividad turística en la Sierra de San Francisco, México

\section{La mercantilización de la vida cotidiana local y sus espacios a través de los performances turísticos}

Este trabajo aporta al giro cultural de los estudios del turismo un enfoque espacial de orden humanístico, que enriquece los alcances del giro performativo en el turismo, pero que también puede ser retomado en los análisis enmarcados dentro del giro crítico de los estudios del turismo, que encuentren en el estudio del territorio una oportunidad para comprender las relaciones que ayudan a perpetuar las condiciones de desigualdad que se dan en los circuitos de producción y consumo del turismo en el neoliberalismo, desde la existencia de los sujetos.

La cultura ranchera y sus espacios de vida son elementos mercantiles que median las relaciones dentro de un performance, y aunque estos no son concebidos así ni por el INAH ni por las y los rancheros, estos sí están conscientes de que su halo cultural es un atractivo para los turistas. Durante las entrevistas, un ranchero expresó que le agradaba la idea de que su rancho fuera considerado un recurso turístico y recibir muchos turistas. Sin embargo, después de reflexionar concluyó que el aumento de turistas beneficiaría su venta de artesanías, pero esto podría implicar perder la tranquilidad en su rancho y llegar a sentirse incómodo en su propio hogar:

\section{No sé si está bien la respuesta, pero hay personas que como le dije, si quieren venir al rancho, no porque están las pinturas, sino para visitar a la familia, o ir al rancho. No, no lo habia pensado como recurso turístico, pero sí, la verdad que sí (Entrevista concedida n. 7, Rancho San Gregorio, México, 2015).}

Los trabajos de campo de 2017 y 2019 permitieron clarificar que las personas que viven en los ranchos californios más cercanos a las rutas de las pinturas rupestres tienen mayor impacto en sus espacios cotidianos por la presencia de turistas. El sitio con mayor número de visitas es la Cueva El Ratón, pero la población de los ranchos cercanos (Los Crestones, San Francisco, Palo Rayo y Guadalupe) no tiene mucho conflicto con los turistas, en algunos casos perciben la visita de los turistas como algo rutinario; sin embargo, han dejado claro que no les agrada que los turistas entren a sus habitaciones a tomar fotografías. Algo similar pasa con la Cueva El Palmarito y los ranchos aledaños, aunque el problema aún no es tan patente.

Los rancheros vinculados a la ruta del cañón de Santa Teresa, la segunda ruta más transitada de la Sierra de San Francisco, está muy 
Daniel Rodríguez-Ventura

Álvaro López López

interesada en seguir trabajando en el turismo: construyeron un área de campamento con sanitarios, venden algunas bebidas frías a los turistas que se quedan ahí. Sin embargo, ellos expresan que no les gusta recibir muchos turistas — no más de tres- en su casa, porque les incomodan y además piensan que antes deben evaluar si tendrán un comportamiento respetuoso y tranquilo.

En el rancho San Gregorio se reconoció que las familias están de acuerdo en que los turistas pasen a su rancho o acampen durante su viaje a las pinturas rupestres; expresaron que ver a los turistas realmente les alegra porque les permite romper su aislamiento cotidiano, esto lo piensa sobre todo la gente mayor y las mujeres que regularmente no salen de este lugar. No obstante, han expresado que les incomoda que los turistas les tomen fotografías sin pedir permiso y más cuando retratan directamente su rostro.

Mientras tanto yo me quedé en su casa a escribir, poco después Martina inició a preparar tortillas de harina, yo aproveché para aprender un poco. Le comenté que si me dejaba tomarle algunas fotos mientras ella preparaba las tortillas y que yo sólo retrataría sus manos, ella contestó que no babia problema, pero me confesó que no le gustan las fotos, al igual que a su esposo, y que se siente en aprietos cuando los turistas la retratan. (Diario de campo, Rancho San Gregorio, México, 2017).

En esta misma ruta a San Gregorio se localiza La Soledad; una de las familias de este lugar expresó que se sienten muy honrados y reconocidos por ser rancheros de la Sierra de San Francisco cuando los turistas se detienen en su rancho a acampar y a admirar su trabajo cotidiano.

\section{Conclusiones}

Una de las contribuciones teóricas y metodológicas de este artículo es el uso potencial del giro performativo del turismo para abstraer sus elementos y actores involucrados, y así conducir una reflexión sobre la espacialidad de la vida cotidiana de los habitantes de un espacio heterogéneo organizado y escenificado para el turismo. Lo anterior permitió reflexionar sobre lo empírico e identificar las relaciones inequitativas entre los deseos e intereses entre los turistas, las turoperadoras, el INAH y los rancheros californios, sobre todo porque el objetivo del texto teatral es lograr la sustentabilidad. Ésta se busca a partir de la organización institucional de un escenario turístico enfocado al patrimonio arqueológico, cuando que en la realidad los intereses económicos turísticos están lucrando con el patrimonio inmaterial de los
Espacios cotidianos de los rancheros californios y performatividad turística en la Sierra de San Francisco, México

rancheros californios, sin que éstos - pese a su deseo de aumentar sus ingresos a partir de esta actividad - obtengan un pago justo y reconocido oficialmente; en cambio, sí son los receptores de situaciones incómodas generadas por la dinámica turística, a modo de externalidades. Por tanto, se considera valido trasladar este nuevo enfoque con otros casos de estudio en los que convergen el turismo y la vida cotidiana de los habitantes en un mismo territorio.

Las particularidades históricas y patrimoniales de los espacios de la vida cotidiana de los rancheros, así como sus propias actividades económicas y sus deseos personales y comunitarios, en medio de un proceso de globalización, no se deben idealizar como algo prístino, pues a su interior tiene varios problemas que se debieran resolver de forma equitativa y con mayor justicia social, pero un problema que sí se debe atender en el corto y mediano plazo es el hecho de que la cultura local está siendo mercantilizada, sin que sus habitantes sean conscientes de ello y puedan decidir si están o no de acuerdo en ello y cómo debieran enfrentar esta situación. Esto se señala porque hay individuos o grupos externos que obtienen importantes ganancias económicas con la cosificación de la cultura y ello no es compartido con las poblaciones rancheras californias, las cuales deben decidir los límites que deben tener los performances turísticos.

Con base en los resultados de esta investigación es importante que en los instrumentos de planeación y gestión del patrimonio se incluya la visión subjetiva espacial de los anfitriones, en tanto que su espacio puede ser incluido como escenario de la actividad turística, o bien, puede ser convertido en un recurso turístico. En este sentido, se podría abrir una línea de investigación, donde los aportes de la geografía humanística, el "espacio de vida" y el "espacio vivido" tengan una participación central en la organización y ordenación de los territorios. Esto se plantea puesto que en general los instrumentos de planeación y gestión son construidos a partir de una reflexión pragmática del uso del espacio y no desde las subjetividades de sus habitantes, las cuales, a futuro, son determinantes en su valoración positiva o negativa de la actividad turística, así como de las políticas de planeación y ordenamiento territorial.

Es importante considerar que los animales no humanos como caballos, burros, machos y mulas, llamados "bestias" por los rancheros californios, tienen un papel importante en el desarrollo de los performances turísticos que se dan en las pinturas rupestres de la Sierra de San Francisco, pues son los que cargan personas y pesados equipajes durante muchas horas de camino. Durante los trabajos de campo se observó que el maltrato de burros y bestias es ocultado por los guías 
Daniel Rodríguez-Ventura

Álvaro López López

para no perturbar las representaciones de los turistas, quienes en su mayoría desacreditan el maltrato animal, sin embargo, también son los turistas quienes normalizan el maltrato al que otras especies son sometidas durante sus viajes. En realidad, ambas situaciones develan formas típicas de la zoo-esclavitud y especismo en contextos turísticos, lo cual se está analizando crecientemente desde perspectivas poshumanistas del turismo, que parten de la idea de transferir las preocupaciones éticas en términos de las desigualdades humanas a las desigualdades entre humanos y otros animales, a partir de la máxima de que todos ellos son seres sintientes y autoconscientes de su dolor y placer. Este no fue un asunto que se hubiera planteado como parte del objetivo de esta investigación, sin embargo, esta última reflexión concluyente, derivada del giro performativo, puede ser el punto de partida para continuar la investigación sobre la mercantilización de los elementos que son parte del turismo en la Sierra de San Francisco.

\section{Referencias bibliográficas}

Alvarado, I. \& López, Á. (Eds.). (2018). Turismo, patrimonio y representaciones espaciales. Tenerife: PASOS.

http://www.pasosonline.org/es/coleccion es/pasos-edita/160-numero-22-turismopatrimonio-y-representaciones-espaciales.

Alvarado, I., Zamora, F. \& López, Á. (2018). Representaciones espaciales, patrimonio y turismo: apuntes teórico-metodológicos. In I. Alvarado \& Á. López (Eds.). Turismo, patrimonio y representaciones espaciales (pp. 2752). Tenerife: PASOS.

Ángel, D. (2011). La hermenéutica y los métodos de investigación en ciencias sociales. Estudios De Filosofía, (44), 9-37. https://revistas.udea.edu.co/index.php/es tudios_de_filosofia/article/view/12633.

Baxter, J. \& Eyles, J. (1997). Evaluating Qualitative Research in Social Geography: Establishing 'Rigour' in Interview Analysis. Transactions of the Institute of British Geographers, 22(4), 505525. https://doi.org/10.1111/j.00202754.1997.00505.x.

Buttimer, A. (2001). Humanistic Geography. In N. Smelser \& P. Baltes (Eds.). Encyclopedia of the Social \& Behavioral Sciences (pp. 7062-7067). Pérgamo: Elsevier.

Bianchi, R. (2009). The 'Critical Turn' in Tourism Studies: A Radical Critique. Tourism Geographies, 11(4), 484-504.
Espacios cotidianos de los rancheros californios y performatividad turística en la Sierra de San Francisco, México

https://doi.org/10.1080/14616680903262 653.

Cariño, M. \& Davis, L. (Eds.). (2007). Sudcalifornia: De sus orígenes a nuestros días. La Paz: Universidad Autónoma de Baja California Sur.

Cope, M. (2005). Coding qualitative data. In I. Hay (Ed.). Qualitative research methods in human geography (pp. 223-233). New York: Oxford University Press.

Crosby, H. (1997). The cave paintings of Baja California: Discovering the great murals of an unknown people. San Diego: Sunbelt Publications.

Crosby, H. (2010). Los últimos californios. México: Instituto Sudcaliforniano de Cultura del Gobierno del Estado de Baja California Sur.

Doctor, A. (2011). El itinerario como herramienta para la puesta en valor turístico del patrimonio territorial. Cuadernos de turismo, (27), 273-289. http:/ / www.redalyc.org/articulo.oa?id=39 820898016.

Edensor, T. (2000). Staging tourism: Tourists as Performers. Annals of Tourism Research, 27(2), 322-344. https://doi.org/10.1016/S01607383(99)00082-1.

Edensor, T. (2001). Performing tourism, staging tourism: (Re)producing tourist space and practice. Tourist Studies, 1(1), 59-81. https://doi.org/10.1177/14687976010010 0104.

Entrikin, J. (1976). Contemporary Humanism in Geography. Annals of Association of American Geographers, 66(4), 615-632. https://www.jstor.org/stable/2569260?ori gin=JSTOR-pdf\&seq $=1$.

Estébanez, J. (1982). La geografía humanística. Anales de Geografía de la Universidad Complutense, (2), 11-31. https://dialnet.unirioja.es/servlet/articulo ?codigo $=86164$.

Estrada, M. (2000). La vida y el mundo: distinción conceptual entre mundo de vida y vida cotidiana. Sociológica, (43), 103-151. http://www.sociologicamexico.azc.uam.m $\mathrm{x} /$ index.php/Sociologica/article/view/48 3.

Ewing, E., McClintock, C. \& McClintock, G. (Productores) \& McClintock, C. (Director). (2008). Corazón Vaquero: The Heart of the 
Daniel Rodríguez-Ventura

Álvaro López López

Cowboy [Documental]. Estados Unidos de Norte América: Lindeza Films.

Feria, J. (2010). Patrimonio territorial y desarrollo sostenible: un estudio comparativo en Iberoamérica y España. Estudios Geográficos, 71(268), 129-159. https://doi.org/10.3989/estgeogr.0472.

Flick, U. (2014). El diseño de la investigación cualitativa. Investigación cualitativa. Madrid: Ediciones Morata.

Føllesdal, D. (1992). El concepto de Lebenswelt en Husserl. Boletín de la Sociedad Española de Fenomenologia, (4), 49-77. https://www2.uned.es/dpto_fim/InvFen /InvFen00/Boletin04/03_FOLLESDAL. pdf.

García, M. \& La Calle, M. (2012). Capacidad de carga en grandes recursos turísticoculturales. Anales de Geografía de la Universidad Complutense, 32(2), 253-274. https://doi.org/10.5209/rev_AGUC.2012 .v32.n2.39720.

Goffman, E. (1959). The Presentation of Self in Everyday Life. New York: Doubleday Anchor.

González, A. (2004). El anfitrión como actor social en el turismo. Reflexiones desde el caso de Ixtapan de la Sal, México. Revista de Ciencias Sociales, $\quad$ III(105), 155-168. http://www.redalyc.org/articulo.oa?id=15 310511.

Gutiérrez, M. (2013). Paisajes ancestrales. Identidad, memoria y arte rupestre en las cordilleras centrales de la península de Baja California (Tesis doctoral). Escuela Nacional de Antropología e Historia, México.

Gutiérrez, M., Hambleton, E., Hyland, J. \& Stanley, N. (1996). The management of World Heritage sites in remote areas: The Sierra de San Francisco, Baja California, Mexico. Conservation and Management of Archaeological Sites, 1(4), 209-225. https://doi.org/10.1179/13505039679313 9024.

Hambleton, E. (2010). Lienzos de piedra: Pintura rupestre en la península de Baja California. La Paz: Gobierno de Baja California Sur.

Hannam, K. \& Knox, D. (2010). Understanding tourism: A critical introduction. Los Angeles; Londres: SAGE.

Harper, S. (1987). A humanistic approach to the study of rural populations. Journal of Rural Studies, 3(4), 309-319.
Espacios cotidianos de los rancheros californios y performatividad turística en la Sierra de San Francisco, México

https://doi.org/10.1016/07430167(87)90050-7.

Hay, I. (Ed.). (2005). Qualitative research methods in buman geography. New York: Oxford University Press.

Hiernaux, D. (2008). Una década de cambios: La geografía humana y el estudio del turismo. Scripta Nova - Revista Electrónica de Geografía $y$ Ciencias Sociales, $\operatorname{XII}(270 \quad(87))$. http://www.ub.edu/geocrit/sn/sn270/sn-270-87.htm.

Instituto Nacional de Antropología e Historia. (1994). Plan de Manejo para la zona arqueológica de la Sierra de San Francisco, Baja California Sur, México. La Paz: Instituto Nacional de Antropología e Historia.

Instituto Nacional de Estadística y Geografía. (2012). Conjunto de datos vectoriales de la serie topográfica y de recursos naturales $\begin{array}{llll}\text { escala } & 1: 1 & 000 & 000 .\end{array}$ http://www.inegi.org.mx/geo/contenidos /topografia/infoescala.aspx.

Instituto Nacional de Estadística y Geografía. (2015). Recursos Naturales. http://www.inegi.org.mx/geo/contenidos /recnat/.

Johnson, H. \& Jaffe, J. (Eds.). (2010). Performing Japan: Contemporary expressions of cultural identity. Folkestone: Global Oriental.

Kim, S.-Y. (2010). Illusive utopia: Theater, film, and everyday performance in North Korea. Ann Arbor: University of Michigan Press.

Kockel, U., Craith, M., Clopot, C. \& Tjarve, B. (2020). Heritages, identities and Europe: Exploring cultural forms and expressions. In U. Kockel, C. Clopot, B. Tjarve \& M. Craith (Eds.). Critical heritages of Europe. Heritage and festivals in Europe. Performing identities (pp. 1-17). New York: Routledge.

Lalive, C. (2008). La vida cotidiana: Construcción de un concepto sociológico y antropológico. Sociedad Hoy, (14), 9-31. https://www.redalyc.org/pdf/902/902151 58002.pdf.

Larsen, J. (2012). Performance, space and tourism. In J. Wilson (Ed.). The Routledge handbook of tourism geographies (67 - 73). Abingdon, New York: Routledge.

Lindón, A. (1997). El trabajo y la vida cotidiana. Un enfoque desde los espacios de vida. Economia Sociedad y Territorio, 1(1), 177-202. https://doi.org/10.22136/est001997490. 
Daniel Rodríguez-Ventura

Álvaro López López

Lindón, A. (2006a). Cotidianidad y espacialidad: La experiencia de la precariedad. In C. Contreras \& A. Narváez (Eds.). La experiencia de la ciudad y el trabajo como espacios de vida (pp. 45-75). México: Colef; Plaza y Valdés.

Lindón, A. (2006b). Geografía de la vida cotidiana. In A. Lindón \& D. Hiernaux (Eds.). Tratado de geografía bumana (pp. 356-400). Barcelona: Anthropos.

Magaña, M. (2010). Indios, soldados y rancheros: Poblamiento, memoria e identidades en el área central de las Californias (1769-1870). La Paz: Gobierno del Estado de Baja California Sur; Instituto Sudcaliforniano de Cultura; El Colegio de Michoacán; Consejo Nacional para la Cultura y las Artes.

Min, J. (2011). Tour guides and emotional intelligence. Annals of Tourism Research, 38(1), 322-325. https://doi.org/10.1016/j.annals.2010.09. 005.

Nogué, J. (1985). Geografía humanista y paisaje. Anales de Geografia de la Universidad Complutense, (5), 93-107. https://revistas.ucm.es/index.php/AGUC /article/view/AGUC8585110093A.

Ortega, J. (1998). El patrimonio territorial: El territorio como recurso cultural y económico. Ciudades, (4), 31-48. https://doi.org/10.24197/ciudades.04.199 8.31-48.

Pillet, F. (2004). La geografía y las distintas acepciones del espacio geográfico. Investigaciones geográficas, (34), 1-42. https://www.redalyc.org/pdf/176/176034 07.pdf.

Prieto, A. (2009). !Lucha libre! Actuaciones de teatralidad y performance. In D. Adame \& J. Alcántara Mejía (Eds.). Actualidad de las artes escénicas: Perspectiva latinoamericana ( $\mathrm{pp}$. 116-143). Xalapa: Facultad de Teatro, Universidad Veracruzana.

Romero, T. \& Varela, J. (2011). Diagnóstico para el desarrollo comunitario y conservación de las pinturas rupestres de la Sierra de San Francisco a través del turismo de bajo
Espacios cotidianos de los rancheros californios y performatividad turística en la Sierra de San Francisco, México

impacto. México: Pronatura Noroeste A.C.; United Nations Fundations. http://sierrasanfrancisco.com/pdf/DIAG NOSTICO.pdf.

Russell, I. (2006). Images, representations and heritage: Moving beyond modern approaches to archaeology. New York: Springer.

Saldaña, J. (2013). The coding manual for qualitative researchers. Los Angeles: SAGE.

Sancho, A. (1998). Introducción al turismo. Madrid: Organización Mundial del Turismo.

Schechner, R. (2003). Performance theory. London, New York: Routledge.

Schechner, R. \& Brady, S. (Eds.). (2013). Performance studies: An introduction. London; New York: Routledge.

Silveira, M. (2006). O espaço geográfico: Da perspectiva geométrica à perspectiva existencial. GEOUSP: Espaço e Tempo, 10(2), 81-91.

https://doi.org/10.11606/issn.21790892.geousp.2006.73991.

Spradley, J. (1980). Participant observation. New York: Holt Rinehart and Winston.

Taylor, D. (2011). Introducción. Performance, teoría y práctica. In D. Taylor \& M. Fuentes (Eds.). Arte universal. Estudios avanzados de performance (pp. 7-30). Ciudad de México: Fondo de Cultura Económica.

Taylor, S. \& Bogdan, R. (1992). Introducción a los métodos cualitativos de investigación: La búsqueda de significados. Barcelona: Paidós Ibérica.

Troitiño, M. (1998). Patrimonio arquitectónico, cultura y territorio. Cindades, (4), 95-104. https://dialnet.unirioja.es/servlet/articulo ?codigo $=2241051$.

Viñas, R. \& Rosell, J. (2009). Las representaciones rupestres de la fauna de Cueva Pintada: Los Cérvidos (Sierra de San Francisco, Baja California Sur, México). Archaeobois, (3), 88103.

https://dialnet.unirioja.es/descarga/articul o/3200030.pdf.

\section{Nota}

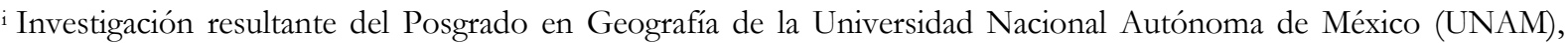
financiada por el Consejo Nacional de Ciencia y Tecnología (CONACYT) y por el Programa de Apoyo a los Estudios de Posgrado (PAEP) de la UNAM. 